Meeting of the Aristotelian Society at 74, Grosvenor Street, W.1, on July 5th, 1920, at 8 P.M.

\title{
XII.-MYSTICISM TRUE AND FALSE.
}

By W. F. GeIKIE-CoBb.

Two questions are to occupy us in this paper: the fact of mysticism and its value for philosophy. That mysticism is is one thing; what it is is another thing, and it is one of the functions of philosophy to decide this latter question.

Our initial difficulty is due to the many shades of meaning with which the terms mystic and mysticism are charged. And of this variety a few examples may be usefully given. "All mysticism asserts, in contradistinction from the external, mechanical and dualistic character of ordinary orthodoxy, the immediate character of religious values."* "Mysticism is religion in its most concentrated and exclusive form "; it is "that attitude of mind in which all other relations are swallowed up in the relation of the soul to God." $\dagger$ "That occupation with the spiritual world which is of the essence of mysticism inevitably involves a view that at the least lightly esteems the world of sense." $\ddagger$ "The conception (of the subliminal Self) is one which has hitherto been regarded as purely mystical." $\$$ "The mystics of all ages have been so far justified in their contention that the form of our experience which presents the truest analogy to the experience of the Absolute must be suprarelational, or, in other words, that the most real type of finite experience must be one which transcends the distinction

* Höffding, Phil. of Religion, p. 214.

+ Edward Caird, The Evolution of Theology in the Greek Philosophers, ii, 210.

$\ddagger$ Encycl. of Religion and Ethics, ix, 114A.

§ F. W. H. Myers, Human Personality, p. 13. 
of subject and predicate."* And again, "In holding that all genuine individuality, finite or infinite, involves a type of immediate felt unity which transcends reduction to the relational categories of thought and will, we may fairly be said to have reached a conclusion which, in a sense is mystical," $\dagger$ and in his Problem of Conduct, he says truly: "As the Alexandrian Platonists knew, it is not by knowledge or science, but in an intuition that is something more and less than knowledge, and cannot be described in language appropriate to our roundabout conceptual modes of experience, that the absolute whole, if apprehended at all, would have to be apprehended." So Dr. McTaggart: "A mysticism which ignored the claims of the understanding would no doubt be doomed. None ever went about to break logic, but in the end logic broke him. But there is a mysticism which starts from the standpoint of the understanding, and only departs from it in so far as that standpoint shows itself not to be ultimate, but to postulate something beyond itself. To transcend the lower is not to ignore it," $§$ and "The view that selves are manifestations of the Absolute, in such a way that they change and perish while the Absolute remains unchanged is one which has always had an attraction for mystics. It is: especially prominent among oriental thinkers." $\|$ "The course of philosophy is the transformation of the mystical conceptions of genius into rational cognition." optimism Leslie Stephen remarks that "its adherents are ready to admit that the pure reason requires the support of the emotions before such a doctrine can be established, and are therefore marked by a certain tinge of mysticism "; the rest " have not been able to escape into any mystic rapture."**

* A. E. Taylor, Elemonts of Metaphysic, p. 152.

+ Ibid., p. 413 .

$\ddagger$ P. 306.

Studies in Hegelian Cosmology, p. 292.

II Ibid., p. 33.

T E. von Hartmann, Philosophy of the Unconscious, ii, 234.

** An Agnostic's Apology, pp. 36-37. 
Miss Jane Harrison in asking how a dead man can be a daimon of fertility objects that " the two aspects are incompatible, even contradictory-death and life are not the same, though mysticism constantly seeks to blend them." Nettleship says that "true mysticism is the consciousness that everything which we experience, every 'fact' is an element and only an element in 'the fact,' i.e., that in being what it is' it is significant or symbolic of more.t Speaking of the Dionysian type of religion, Mr. Cornford says: "Because the province of a Mystery God is always, primarily, the human society from which he immediately springs, it is possible for him to remain human as well as divine. In this lies the secret of the vitality of mystieal religion." + So Höffding says that "the feeling of love has a mystical character due to the arousing of uncomprehended organic instincts, and to the influence of these on the vital feeling and on the imagination." $\$$ And again: "Value can only be preserved by means of changes and transformations. This state of things depends on the reality of the temporal relation and the reality of differences in general. Only by way of pure mysticism, the logical outcome of which is ecstasy, can we (sometimes) attain to a disregard of this order of things." $\|$

Royce, while affirming that Mysticism is "not a vaguely applied name for superstition in general, or for beliefs in spirits, in special revelations, and in magic" says that "for the mystic, according to the genuinely historical definition of what constitutes speculative Mysticism, to be real means to be in such wise Immediate that, in the presence of this immediacy, all thought and all ideas, absolutely satisfied, are quenched, so that the finite search ceases, and the Other is no longer another, but

\footnotetext{
* Themis., p. 269.

+ Philosophical Remains, p. 32.

$\ddagger$ From Religion to Philosophy, p. 112.

$\$$ Outlines of Psychology, p. 77.

II Philosophy of Religion, p. 252.
} 
is absolutely found." And "the true historical importance of Mysticism lies not in the subject to which it applied the predicate real, but in the view it holds of the fundamental meaning of that very ontological predicate itself . . . Mysticism consists in asserting that to be means, simply and wholly, to be immediate." $\dagger$ Yet in spite of his ample recognition of the practical value of Mysticism, Royce in the end rejects it as a metaphysical guide, on the ground that like Realism it is a mere abstraction, and ends in a salto mortale from the world of the Manifold into the One which is zero. "The mystic ignores the sum of the series. He cares only for the final term itself, viewed as the limit which the other terms approach." $\ddagger$ Since Royce confines his criticism of Mysticism to its speculative activity this conclusion is not surprising. But speculation is not the peculiar work of Mysticism; it does not define its. essence; it is hardly a property of it, and is probably not more than an accident.

Plotinus lends no countenance to the suggestion that Mysticism is essentially speculative. In the mystical vision there are not two things, but seer and seen are one. "Perhaps we ought not to speak of vision; it is rather another way of seeing, an ectasy and a simplifying, a self-abandonment, a yearning for a touch, rest, and a striving after union with what is to be seen in the sanctuary." $§$ So again: "The soul being filled with deity brings forth these (beauty, justice, virtue). And this is both the beginning and end to the soul. It is the beginning indeed, because she originates from thence; but it is the end because the Good is there, and because when the soul is situated there, she becomes what she was before .... Since the soul is different from God, but is derived from him, she. necessarily loves him, and when she is there she has a celestial

* The World and the Individual, p. 144.

+ Ibid., p. 80.

$\ddagger$ Ibid., p. 191.

\$Enn., vi, 9-11. 
love; but the love which she here possesses is common and vulgar." Finally, Mr. A. B. Sharpe finds himself unable to define Mysticism without the use of the discredited term "supernatural." The characteristic of mystical states is "that they are directly and immediately supernatural." Mysticism is, therefore, a passive state of the soul during which God hinself illuminates it. "The only direct, immediate or experimental knowledge of God that man can attain to must be supernaturally bestowed upon him." $†$

It seemed necessary to cite reputable authors on behalf of the claims of Mysticism, because of the dislike, expressed or unexpressed, felt by professed philosophers for it. Their altitude towards it is perhaps well illustrated by a remark made by Talleyrand when the Host passed by in procession : "Nous nous saluons mais nous ne parlons pas." The above citations may serve as sufficient testimony that Mysticism represents a series of facts of experience, and also that it is a term of art which it is specially difficult to define with precision. It seems impossible, however, to dislodge from popular language the loose sense of the term mysticism.

In spite, however, of the appeal to the supernatual as alone constitutive of the mystic experience, it would seem that mysticism has a double aspect, one preparatory, or partial, or perhaps improper, and one final, complete and proper. The former is to be recognized in the search for the meaning of things, and the latter in the ecstatic experience in which subject and object melt into that mysterious Somewhat which is the ground of subject and object alike. Partial and successive experiences of a mystical character form a cumulative disposition which has its term in the mystical experience proper, much as progressive modifications of a structure emerge through epigenesis into something which, when it appears, we call a new creature.

\footnotetext{
* Ibid., vi, 9, 9.

† Mysticism: Its True Value, pp. 61, 14.
} 
A. It will perhaps be most useful if we illustrate a little what has been just called partial mysticism. And we will take first that study of nature which we call-

a. Science.-All men are concerned with a study of the nature of things and the uses and purposes to be found in them. And it makes no difference to our present inquiry whether they are studied for a practical or theoretical end indeed, these ar $\theta$ at bottom indistinguishable, for the establishment of a complete theory has a practical value; the doctrine of the Absolute, for example, is as truly a practical as a theoretical good. The exact study of things, then, is an attempt to trace them back to their origin and to follow them to their final cause, and every success in ascertaining their nature is of a mystic character, inasmuch as it is a discovery of some aspect of the Reality hidden behind the Appearance. For Mysticism assumes that the life is more than the form, and it is incompatible with all realistic striving to state philosophic thought, or any other activity of life in mathematical formulæ.

$\beta$. Mysticism is the ultimate explanation of phenomena such as those presented by instinct or impulse. The most. thoroughgoing phylogenetic inquiry into instinct comes to a pause before the end is reached. The theory of heredity, even. though carried back to account for pre-human antecedents, or pre-historic conditions, leaves us still with some unknown cause not to be found in the history of the object. Even so no doubt it will be found that omnia exeunt in mysterium, but at all events the mystic's hypothesis does carry us back, as does. philosophic thought with which here it runs parallel, a stage further than science can. And to carry a process a step further back is always so far a service to science.

$\gamma$. The theory of evolution, or, more technically, of epigenesis, seems incapable of being unified without a dose of mysticism. For, presuming all species to have been derived from primordial protoplasm, we have to account for the power which has produced the many species out of the one root of their 
existence. We have to account also for the adaptive power which has given success to the survivors, for as all are supposed to have started on equal terms, we must assume an unknown $x$, which has acted as a differentiating factor. But. this $x$ making for improvement in the case of some species has a teleological value, and having the whole in view we can but recognive it as mystical.

We may reach the same result by the way of psychology. When Dr. Ward explains* that pleasure is one thing and pleasures another, and that these latter become graded into higher and lower through accommodation and novelty, he is building on the fact that there is a power at work which constructs qualitative differences out of quantitative. But this fact is not obvious so long as natural differences occupy the attention exclusively; indeed it may appear to be not applicable to an enumerative whole when the many examples of degeneration are considered. Hence, if we conclude for a tendency to improvement in every lower organism we shall be applying a pre-judgment mystically arrived at, i.e., by an intuition of the nature of the whole.

$\delta$. A new chapter in human knowledge has been opened by anthropology with its description of folk-beliefs and customs. But these latter have been treated ordinarily as being merely the rude and primitive beginnings of our later culture. And little attention has been directed to the question of their validity. Rather, the assumption has been made that they have been over-lived, and that they have, therefore, ceased to have more interest for us than as landmarks of a longforgotten and obsulete stage in our own development. Yet a closer scrutiny might disclose the fact that as a general rule folk-psychology, if formally false, is materially a true transcript of Reality. The universal belief of the savage in gods, whether high or low, celestial or telluric, witnesses to man's innate 
sense of the principle of Otherness, and is at all events more rational than the later attempt to dispense with the Other in favour of Self-deification. That the principle of Otherness should have held undisputed sway in periods when criticism was in possession of no scientific instrument is remarkable, and perhaps inexplicable, unless we have recourse to the hypothesis that man's mind is determined not only by a view of the Manifold, but also and concurrently by a synoptic view. But every synoptic view is identical with what our authorities are agreed in calling mystical.

є. Since Rousseau's day many thinkers have insisted on his doctrine of a general will as the expression of the conation of a community. On the other hand, voices have been raised from time to time urging that psychological concepts are made chaotic by any such doctrine. And these latter seem to plead the better cause. Yet a man who urges that England, or the Catholic Church, stands for something more than a joint will of all, or for more than the joint agreement of the numbers of a governing junta, can hardly be silenced. Here too the solution of the antinomy seems to be in the mystic's hands. The will of the individual is the type of all will, and his will is distinct from the several wills of the rest, but it is not a separate will. It is a phase, perhaps a moment, of the universal will of the Absolute, the phenomenal expression of the one will. Similarly, every several will in the community converges on the same universal will, and at the same time expresses it. And if it be said that these several wills are over a large area contradictory of each other, the answer is direct; the volitions may be contradictory, but the "standing will," if we probe deep enough, will be found self-identical. The general will might be indeed accounted for on the supposition of the over-ruling

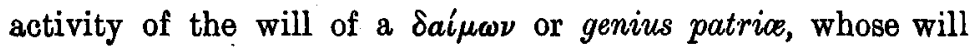
would be the standing will of all. But such a will would still be singular, and would have to use persuasion or coercion to secure the adhesion of the several wills of the members of the 
community. In the former case, what would be operative in the phenomenal order would be the wills of the members acting jointly; in the latter case there would be no will at all, for freedom would be wanting. But whether acting directly through immanence, or indirectly through a departmental presiding officer, the will of the one is supreme over all lesser wills, and this conclusion is a product of mystic intuition.

$\zeta$. The mystic is a devout lover of Nature. To him, "waving its row of lamps the universe sings in worship day and night. There the sound of the unseen bells is heard; there the Lord of all sitteth on his throne." The air is full of daimons, and the earth of the knowledge of the Lord. Nature is, for him, a treasure-house of natural and necessary symbols, and hence the creation of arbitrary and fanciful symbols is an impertinence, or a disease. True symbolism is gained from Nature by intuition, and rests on a system of correspondences where wheels revolve within wheels, for the spirit of the living creature is in the wheels. The mystic is untouched by any reminder that Nature is red in tooth and claw with ravine. He denies the fact, or explains it away, or disregards it as being an irrelevance. His intuition is of the unity, and as a mystic he takes little heed of the differences, holding them to be but incident to progress towards the perfection of the whole. If Nature be the vesture of the invisible King, then it is the King on whom the attention of the mystic is rivetted. The vesture has but a mediate value and is comparatively negligible.

In these examples of a partial or improper mysticism we note that the mysticism is of a nature akin to instinct. It dimly sees, but does not apprehend its object, and it builds on past experiences which now form the structure of the Unconscious. In fact, the mystic impulse is at once the ground of instinct, impulse, folk-beliefs, and the feeling for Nature, and also the vivifying principle which assures them their form and persistence in the Unconscious. Nature itself is in all those shapes already deposited in the Unconscious by æonian 
experience. It is, however, the function of consciousness to survey the phenomena of the inner and the outer life in the light of reason, to point to their unity of origin and texture, and to bring the Manifold of experience under the One whose existence is a mystical postulate suggested by the intuitive unity of man's own mystical being.

B. The mysticism which we have up till now been considering is but the forecourt of the temple. It enshrines what has been; it suggests the ground on which the palace of Truth itself shall be erected. It is conservative rather than progressive. It assumes what cannot be demonstrated-an upward tendency in the world; asserts that what has been achieved is but an earnest of what shall yet be done; and, most important of all, maintains that the mind of man is in living union with a spirit, or power, which is the spirit, or power, whose peculiar function it is to draw under law all things to their perfection in the whole.

In the last paragraph we seem to have reached the parting of the ways between the mysticism which is true and the mysticism which is false. The mysticism which springs from the Unconscious, which is the sum of our past, human and prehuman, is not mysticism proper but memory. It seems to act in the same way as mysticism proper, but the appearance is fallacious. Its characteristic modes of activity are to be seen in mediumship, in speculation in nubibus, in autovatic writing, crystal-gazing, inspirational writing, clairvoys:u, and clairaudience, and in all similar phenomena. These all alike have their utility in revealing to us the nature and extent of the buried treasures of memory, and in reminding us, by the contrast they afford between the foundations of the Conscious and the formless ghosts of the Unconscious, how correct was the Greek thought which assigned good to the limited and evil to the infinite.

True mysticism, on the other hand, is of a forward look. Its roots are not in the earth but in the eternal Reason which over- 
shadows and penetrates all thinking. Hence, every mystical activity proper is due to the inspiration of a higher power with which the mind of man is in touch by virtue of its kinship of nature. The mystic experience begins as intuition and is perfected in judgment.* It is true that the intuition is often so evanescent as to elude the grasp of reflection. It has but a glimpse "of incomprehensibles, and thoughts about things which thoughts but tenderly touch." But it does not seem to be correct to refer this intuition to feeling, if feeling be "the one capacity of the pure ego," by which it is either pleased or displeased with its presentation. Rather, the intuition is the beginning of thought, and may, or may not, succeed in vindicating its right to become thought. The cases, therefore, in which it succeeds should be taken as illustrating the character of those in which it fails. Thus we should conclude that all mystic intuition is neither thought nor feeling, but that the consequent activity concerned comes under the category of thought, and not properly of feeling, though of course here as everywhere some feeling is an accompaniment of the thought. In other words, mysticism proper is the most positive form which a moral valuation can take. It is a revelation not so much of the true as of the good; and though the good and the true have aspects in common, it has a positive, personal, unquestioning quality which is a necessary feature of a moral valuation even as we know it, whatever thought's ideal claims may be. It would follow from this that mystical experiences would be much more common were not most people content to take a shabby intellectualist interpretation of their most vital moments.

Mysticism, then, is an immediate apprehension of some interior good comparable to the immediate knowledge we have

* The mystical conception begins with the phenomena of imagination, and, provided nothing intervenes to disturb or interrupt, it is completed by an act of powerful intellection (Récejac: The Bases of the Mystic Knowledge, p. 109). 
of the objects of the external world. It is empirical and not speculative. Saint Teresa (an unexceptionable witness) says of herself that " a feeling of the presence of God would come over me unexpectedly, so that I could in no wise doubt either that $\mathrm{He}$ was within me, or that I was wholly absorbed in Him. It was not by way of vision; I believe it was what is called mystical theology."* So Scaramelli says : $\dagger$ "As the human body touches another body and is touched by it again, as it thus feels the other's presence, and this sometimes with enjoyment; so the soul touches a spiritual substance, and is touched by it again, and feels the presence with the sensation that pertains to pure spirit, and this sometimes with great delight; for example, when it is God who touches her and is present to her."

But it is not necessary to labour proof of the proposition that mysticism is by common consent an empirical knowledge of, or direct acquaintance with, a presented non-sensuous Good. Not only is Catholic mysticism at one about this, but Sufi mysticism, and indeed all mystijism, is in agreement. All mystics affirm also that their knowledge is intuitive, and as such is ineffable, incommunicable. That knowledge alone, which depends on facts, or on ideas of Reason, can be communicated; all that lies beyond these lies also beyond logic, and to be known must be lived through. But it is just this world of the beyond, this "excessive," which is the object of the mystic's awareness. And this world, by its very nature, is self-excluded from the operations of the intellect. Hence Philosophy is not called upon to pass judgment either on the fact that it is, or on what it is, apart from its expression. Its function in this respect is to pronounce merely whether what the reporter of a mystic experience says is or is not contradictory of its own accepted conclusions. But since these are confined to what Sense and Understanding jointly supply, and since mystic data 
are beyond these, Philosophy can only say: "Non ragionam di lor, ma guarda e passa." In other words, the function of philosophy when mysticism comes before it, is to accept the data of the latter as it does the data of the sensuous order, and then to find a place for them in its system of thought. In this sense the mystical intuition is perfected in judgment, even though here as elsewhere much of the living fact evaporates in the process of abstraction.

Here the objection might naturally be made that if the data of mysticism are of this intractable character their solution would be better found in hallucination, or alienation, than in the hypothesis of a reason of the heart which lies beyond the reasonings of the intellect. But in the first place it is noteworthy that acknowledged mystics have shown themselves on their guard against these aberrations of the mind. The delight that comes from feelings or visions is "very suspicious to come from the enemy," says Hilton. "It is more natural that God should communicate Himself through the spirit than through the senses," says St. John of the Cross. "It is very important to prevent souls from resting in visions and ecstasies; these graces are greatly subject to illusions; of this sort of gifts, the least pure, and those most subject to illusion, are visions and ecstasies," says Madame Guyon. We may say in general that the truer the mysticism the greater the caution shown in discriminating between the true and the false.* And, speaking generally again, the test by which all auditions and visions, whether intellectual, imaginary, or corporeal, are tried, is not only the circumstances of their happening, but even much more their value. Revelations of any sort, if genuine, must inure to the heightening of the life of the spirit, must be clear, free from self-seeking, not

* Cf. Hilton, The Scale of Perfection, i, xi ; St. John of the Cross, Subida del Monte Carmelo, i, xi ; Guyon, Vie, i, ix ; Father Poullain, The Graces of Interior Prayer, chs. xxi, xxii ; Gerson, De distinctione verarum visionum. 
self-contradictory, not referable to human agency, properly attested, and purely transmitted. And even so they are to be accepted with caution, and are not to be used as foundation for doctrine, but, though approved, are not more than "probabiles et pie credibiles."

In the second place, between pathological hallucinations and alienation and the mystic's sense of the presence of God, there is the difference of a whole scale of values. Between free memory-images and morbid hallucinations, are many degrees of reality, and in all a minimum of sensuous impressions is present. But the hallucination consists in the projection of a representation whereby it is mistaken for a presentation. The mystic's experience, on the contrary, whether jnstifiable or not, is, at all events, not of a hallucinatory character, because it lacks all reference to corporeal reality. "The immediate vision of the naked Godhead," says Suso, "is without doubt the pure truth; a vision is to be esteemed the more noble the more intellectual it is, the more it is stripped of all image and approaches the state of pure contemplation." * And although theologians have discussed the question whether the two outstanding figures of Catholic faith have appeared in bodily form, the evidence of the mystics themselves is against the supposition. St. Teresa, for instance, says that "when anyone can contemplate the sight of our Lord for a long time, I do not believe it is a vision, but rather some overmastering idea." $\dagger$ And in general, the visions, locutions and auditions of mystic literature seem explicable in terms of ordinary psychology.

We are here reminded that the mystic experience proper is one thing, and the mode of its formulation is another. The vision is as long-lived as a flash of lightning, but before it is gone the mind has given it intellectual form. The essence

+ Int. Castle, Sixth Mansion, ix, 5. 
of the mystical experience consists in a transcendental appre. hension of the reality which appears in all ordinary experience. These appearances, according to mysticism, are the garment worn by the reality on which perhaps no man can look and live. The myth of Zeus and Semele enshrines a law. But the mind of man presses towards awareness, and awareness implies a mental form; but the form can hardly comprehend the full content of the concrete reality, the touch of which makes the mystic. Hence the form by which the seer seeks to repressent to himself that reality is inadequate, and if pressed, is misleading. The mystic is not mistaken when he affirms that the boundaries of the flaming world have for him for a brief moment been removed, but he cannot for all that be enabled to claim for his private explanation of that experience greater validity than that of a working hypothesis.

This is only to say that the mystic's explanation cannot transcend the limits of symbolism. The touch of reality is an inexplicable fact; the formulation of it by the mind is symbolic. The one is an "irruption" of the Absolute into consciousness; the other is the figurative expression by the mind of that which in itself is inexpressible. Indeed, every real particular is inexpressible, for what is expressed must be known as thought, and all thought is universal, and from the universal there has slipped out that particularity which makes the thing to be unique and unsharable. Hence the gulf between the that and the what in mystical experience is comparable to the difference which yawns between every that and every what. In all the activities of thought the materials we work with are symbols, the data of science no less than the data of art or of religion. And all are inadequate to express reality. But it should be observed that wherever thought is not a chimoria bombinans in vacuo there is assumed necessarily the same union of the absolute reality and of its appearance, and the same symbolic relation of the latter to the former. The symbol is a joint product of the Absolute and of the materials already 
possessed by the mind for the purposes of thought. Hence, there is no a priori ground for regarding the mystic fact as abnormal and therefore suspicious.

Sensuous experience and mystic experience, then, are alike in that neither is fully expressible, and that whatever gets itself expressed succeeds by the use of symbols. But the symbols used are not deliberately selected by the conscious mind. They emerge from the unconscious. In that-if we may use metaphorical language-are stored up the memory images of all the objects of our experience, or else these are capable of re-creation at need. However we express it, the fact is undoubted but unexplained. A perception, or even a sensation, shades uff into the unknown no more and no less than an apperceptive mass; an element of mysticism lurks in a presentation and lies at the base of all cumulative dispositions. Man can call spirits from his own vasty deep, and they will obey him-sometimes." When they come, he uses them as symbols. He has Pascal's experience, and he cries out "Fire"; he is conscious of a higher Something, and he "feels" or is "touched"; joy enters his heart, and with Richard Rolle he says, " thought into song is turned, and the mind into full sweet sound is changed;" a new angle-point is made effective for the understanding, and the Servitor sings, "Illuminare, illuminare Jerusalem"; a feeling of utter imperfection calls for the variegated imagery of "pilgrimage"; a sense of harmony and

* Many will go further than this and postulate an "ethereal medium" which records not only the things retained in the memory of the individual from his own experience, but also images in an " earth-memory." Thus E. says (Candle of Vision, p. 56): "In tracking to their originals the forms seen in vision we discover for them a varied ancestry, as that some come from the mind of others, and of some we cannot surmise another origin than that they are portions of the memory of Earth which is accessible to us." Personify Earth, and postulate the power of transmission of thought from mind to mind somehow, and all this is credible. But still the record has to be read, and the mind that reads is still the central mystery. 
unity is translated into the language of the "spiritual marriage"; the two-fold experience of an indwelling Spirit and a transcendent Power without is symbolized by the familar doctrines of the Incarnation and the Trinity; Bāyãzid, when he finds in himself the love of God, can only say that "when God loves a man, $\mathrm{He}$ endows him with three qualities in token thereof : a bounty like that of the sea, a sympathy like that of the sun, and a humility like that of the Earth," all of which is couched in symbolic terms; so the Sufis speak of three organs of spiritual communication, the heart which knows God, the spirit which loves Him, and the inmost ground of the soul which contemplates Him. But we should miss the secret of mysticism if took its symbolic utterances for its unutterable experience. And perhaps we may share the robust common-sense of Dr. Johnson who, speaking of Jacob Böhme, said that "if Jacob had seen unutterable things, Jacob should not have attempted to utter them." But, then, how else could others have been stirred to emulate him? Yet the main point is that we get back from symbols, and words, and names, to the mystic fact itself. Jalāluddīn Rūmī, addressing the scholastic theologian, says :-

Do you know a name without a thing answering to it ?

Have you ever plucked a rose from R.O.S.E. ?

You name His name : go, seek the reality named by it !

Look for the moon in the sky, not in the water!

We are driven then from the symbol to the thing symbolized, and though we are compelled to limit ourselves to writing about it, we can perhaps set up one or two signposts on the road for the benefit of the travellers who are also seekers. Each, however, must do the travelling and seeking for himself.

a. The mystic is not seeking to get, or to know. He is seeking to become, and to be. And what that is is the secret known to himself alone. He believes himself to be unique, infinite in his reach, capable of an undreamed of perfection, 
dependent on the "Other" for everything, at once everything and nothing. Yet he does not stand in isolation as if he possessed some secret denied to others, but when asked what he has to claim as his distinguishing mark he can only reply that he has nothing which differs from what all others have; "Where one heard noise, and one saw flame, I only know be named my name." His secret is to himself, but so, he avers, is that of everybody else.

$\beta$. The mystic's devotion is to the Whole which is the One, and in his most characteristic moments his whole being is suffused with a sense that the One alone is, and that the Many are but shadows. Hence, when he incautiously sets out to turn his intuitions into theology he is apt to talk as if his view was pantheistic. The mystic, however, as a mystic, has no creed, and if he is somehow tempted to form a creed, his mysticism is no longer pure but mixed. He has stepped into philosophy; the Good becomes the True, and vov̂s has given way to Stávosa. In any case, pantheism is not the most suitable creed by which to formulate his intuitions, still less is it logically necessary.

But because the mystic is so deeply interested in the one incommutable Good he is open to the charge of neglecting its differentiations for thought. The distinction between good and evil is not for him sharply drawn, nor that between being and not-being. Time and space seem to him negligible, and subject and object imply a division which would be better away. This disinclination to allow for phenomenal differences is ordinarily regarded as the cardinal defect of mysticism. It does not, however, derogate from its essential value, but serves at best as a reminder that it needs for its guardian both science and philosophy.

$\gamma$. It would be a misunderstanding of the mystic if we supposed him to be concerned with his own interior states only. $\mathrm{He}$ does certainly turn away from the external world, as he turns away from all its differences, but he does not thoroughly 
confine his attention to what he finds within himself. If he looks within, as he does, it is because he is aware that there is the Other which is the object of his supreme desire. And so far is he from exalting himself into his object that his whole endeavour is to sink and lose himself in it. No doubt the "introvert" becomes a mystic more readily than the "extrovert," but in the process he tends to disappear, and may indeed be said to become an "extrovert" of a peculiar kind. Or shall we say that the moral experience of the mystic is the arrogation of godhead with the austerity attached to the claim, and with a full sense of responsibility, as well as with the humility which is responsibility's better half?

No term is more generally associated with mysticism than that of ecstasy, and it is on ecstasy that Royce bases his condemnation of mysticism. He regards ecstasy as giving "a certain limiting state of that finite variable which is called your knowledge," and as being the zero into which consciousness disembogues. The error in this judgment is in the assumption that the ecstatic state in transcending consciousness annuls all consciousness. What is unconsciousness with regard to us here is not necessarily unconscious to us there. The intuitive flash of genius, like the ecstatic vision, subsumes ordinary consciousness, and fuses all differences in a whole cognized synoptically. The differences, however, remain as moments in that whole ready for the service of discursive thought. The mystic Absolute is not only the goal but also the process. Consciousness is a transition stage between two different kinds of Unconeciousness, but what it borrows from the lower, and enriches, it transmits to the higher. It does not seem to be true that the mystic supposes that "the finite search has of itself no Being at all, is illusory, is Mâya, is itself nothing." On the contrary, it is an admitted mystic dogma that Reality lives in its appearances; that in the via negativa you strip off the accidental only, so what is left at every stage is real, though not the whole of reality; and that in the via eminentice you 
start with what is real, find more of it as you climb, and at the top of the ladder retain what your discursive reason has garnered, and then intuitively crown it in a synoptic view. The mystic certainly does claim that his intuition puts him in touch with the real, and in this his claim differs in degree only from the claim of the poet that he is in touch with the real in the sensuous. But no mystic has ever claimed that, discursively or intuitively, he cognizes reality in its fullness; and he adds that he is not primarily concerned with reality under its aspect of truth. He differs from the physicist in method, but not in principle; to both finality is impossible.

Lastly, the problem of the mystic is the metaphysical problem of the nature of the self. If this be a mere " bundle or collection of impressions"; if it be nothing but the present thought appropriating the past; or if it be "an average statistical resultant of many conditions, but not an elementary force or fact," then the mystical fact does not emerge. This fact stands or falls with the fact of the transcendental self. Of this self we have no sure knowledge by description, but I submit that we have by acquaintance. I think, and I can add to this that I think that I think; when I make the addition, as I do every day many times, the knower of the object becomes the knower of the subject. In other words, he reveals himself as capable of aćtivity in another capacity or form whereby the subject in the "phenomenal" world becomes an object in the "noumenal."* I, the Self that is aware of $x$, am also aware of my awareness, and I make the judgment on an intuition given by acquaintance that the self which is aware is identical with the self which is aware of the awareness. In that case that self can and does function in the phenomenal and in a world which is transcendental to the phenomenal. That is, it is a member of the transcendental order, and as such it is at home with reality and

* This self is "that subject whose activity is the subject's 'object," Volkmann, Lehrb. d. Prychologie, 4th ed., ii, 217. 
with its two chief aspects. If this be once granted the mystical experience would seem as natural as the sensuous.

$\delta$. The soul, however, to the mystic is not "the apex of a didactical pyramid," a cold abstraction reached by thought. It thinks, of course, but its thought is not that of dry reason, but is informed by the passion of love. And it is because of the dominance in mysticism of love that mysticism has become identified improperly with "feeling." When the soul is in presence of the one "it takes fire, and is carried away by love. The fullest life is the fullest love, and the love comes from the celestial light which streams forth from the Absolute one, the Absolute Good, that supreme principle which made life and made spirit, the source and beginning, which gave spirit to all spiritual things and life to all living things." Plotinus and Plato agree that "love is an activity of the soul desiring the Good." "Love is not a relation between externals, but between Spirit and Spirit. It is unity in duality, the reconciliation of these opposites, known in experience. Human love is the sacrament of the union of souls yonder. It is immortal, almost immortality itself... . . Three classes of men have their feet on the ladder-the philosopher, the friend of the Muses, and the lover. The intellect, æsthetic sensibility, and love, are the three 'anagogic' faculties." $\dagger$ So Richard Rolle says that "burning of love into a soul truly taken all vices purgeth ... for whilst the true lover with strong and fervent desire into God is borne, all things him displease that from the sight of God would run." + Hence the mystic is able to solve in practical form the mystery of pain. He calls suffering the "gymnastic of eternity," and says with a Kempis, "Gloriari in tribulatione non est grave amanti." The vision of the Good enraptures 131.

* Plotinus, Enneads, 6, 7, 23, and W. R. Inge, Gifford Lectures, ii,

+ Inge, ubi supra, p. $187 f$.

+ The Fire of Love, i, xxiii. 
him, and he cries with St. Teresa, "let me suffer or die," because he has learned that it is the sense of the finite ego which shuts off the soul from the incommutable Good, and that it is through suffering that this sense becomes a servant instead of a master. Hence the air of unreality that is apt to cling round the ecstatic utterances of the mystics. The explanation is that they are in love with eternal beauty and that love makes every lesser object of little account. Hence too Pascal's vision of "Feu" ended with " Renonciation totale et douce." Amans volat, currit et loetatur : liber est et non tenetur, says a Kempis. And when Dante at length attained to the vision of the Supreme Light, he could only speak of it as loving and smiling, and give as his last word that it is Love which moves the sun and the other stars. Before this supreme experience of Love, it would seem that all discursive thought is foredoomed to silence as a worshipper in the outer court of reality. 